\title{
Over lust en schoonheid : pleidooi voor een spaarzame verklaring van eetstoornissen
}

Citation for published version (APA):

Jansen, A. T. M. (2000). Over lust en schoonheid : pleidooi voor een spaarzame verklaring van eetstoornissen. Maastricht University. https://doi.org/10.26481/spe.20000101aj

Document status and date:

Published: 01/01/2000

DOI:

10.26481/spe.20000101aj

Document Version:

Publisher's PDF, also known as Version of record

\section{Please check the document version of this publication:}

- A submitted manuscript is the version of the article upon submission and before peer-review. There can be important differences between the submitted version and the official published version of record.

People interested in the research are advised to contact the author for the final version of the publication, or visit the DOI to the publisher's website.

- The final author version and the galley proof are versions of the publication after peer review.

- The final published version features the final layout of the paper including the volume, issue and page numbers.

Link to publication

\footnotetext{
General rights rights.

- You may freely distribute the URL identifying the publication in the public portal. please follow below link for the End User Agreement:

www.umlib.nl/taverne-license

Take down policy

If you believe that this document breaches copyright please contact us at:

repository@maastrichtuniversity.nl

providing details and we will investigate your claim.
}

Copyright and moral rights for the publications made accessible in the public portal are retained by the authors and/or other copyright owners and it is a condition of accessing publications that users recognise and abide by the legal requirements associated with these

- Users may download and print one copy of any publication from the public portal for the purpose of private study or research.

- You may not further distribute the material or use it for any profit-making activity or commercial gain

If the publication is distributed under the terms of Article $25 \mathrm{fa}$ of the Dutch Copyright Act, indicated by the "Taverne" license above, 
Mijnheer de rector, beste collega's en lieve familie, vrienden en vriendinnen,

Nederland heeft zijn eerste "eetprofessor" gekregen en de bijzondere leeropdracht die met het uitspreken van deze rede wordt aanvaard, heeft een enigszins paradoxaal karakter. Het doel van de leeropdracht is immers om de psychologie van eetstoornissen in kaart te brengen, zodat interventies gepleegd kunnen worden die het gestoorde gedrag zo goed en zo efficiënt mogelijk reduceren of zelfs kunnen voorkomen. Is dit het geval, is de psychologie van eetstoornissen zodanig in kaart gebracht dat interventies heilzaam zijn en misschien ook wel preventief, dan heeft deze leeropdracht haar nut verloren. Dus met het uitspreken van deze openbare les doe ik niets meer en niets minder dan u beloven dat ik heel erg mijn best zal doen om mezelf, op deze plek althans, zo snel mogelijk weer overbodig te maken.

Wanneer is dit moment bereikt? Het lijkt in zicht als er een juist antwoord op de volgiende vier vragen gegeven kan worden: hoe ontstaan eetstoornissen, waarom blijven eetstoornissen voortbestaan, hoe zijn eetstoornissen te genezen en hoe zijn eetstoornissen te voorkomen. Het is tamelijk pretentieus om nog voor mijn expiratie op deze vier vragen bevredigende antwoorden te willen geven. Ik koester dan ook niet de illusie dat deze leeropdracht spoedig zijn nut zal verliezen en ik snel werkloos zal zijn, zeker niet gezien de schaarse onderzoekstijd die het 
huidige academische bestel in zijn algemeenheid en het Maastrichtse bestel in het bijzonder garandeert.

Ik zal trachten deze les zo weinig mogelijk beschouwend te laten zijn en zoveel als mogelijk is een inhoudelijk karakter te geven. Dan heeft u er ten minste ook nog iets aan en het strookt met wat ik verderop zal beargumenteren, namelijk dat het uitdragen van kennis van groot belang is. Om te beginnen geef ik $u$ een korte uiteenzetting van het onderwerp van studie. Wat zijn eetstoornissen? Vervolgens behandel ik stuk voor stuk de vier eerder genoemde vragen met $u$. Tijdens die bespreking zult u merken dat we zowel het onderzoekslaboratorium als de klinische behandelkamer en een enkele collegezaal aan zullen doen, om inzichtelijk te maken dat samenwerking tussen onderzoekers van de academie, hulpverleners in de klinische praktijk en docenten - in de breedste zin des woords - van groot belang is.

\section{Wat zijn eetstoornissen?}

Van een eetstoornis wordt officieel gesproken als het eetgedrag zodanig verstoord is geraakt dat het de fysieke gezondheid of het psychosociale functioneren van een individu schaadt (APA, 1994; Fairburn \& Walsh, 1995). Op dit moment onderscheiden we een drietal eetstoornissen:

Anorexia Nervosa, Bulimia Nervosa en de eetstoornissen Niet Anderszins Omschreven, de laatste groep zal ik in het vervolg de NAO's noemen. Anorexia Nervosa is de meest bekende eetstoornis en we spreken daarvan als iemand minder dan $85 \%$ weegt van het gewicht dat 
bij haar leeftijd, lengte en geslacht past, als zij 'intens bang is om in gewicht toe te nemen, een gestoorde perceptie van haar eigen lichaam demonstreert en sinds minimaal drie maanden niet meer menstrueert. Bulimia Nervosa is een wat minder klassieke eetstoomis en werd een decennia of twee, drie geleden voor het eerst officieel beschreven. Van Bulimia Nervosa is sprake als betrokkene met enige regelmaat last van eetbuien heeft. Tijdens de eetbuien wordt er een grote hoeveelheid voedsel geconsumeerd en is er sprake van een gevoel van controleverlies. Patiënten met Bulimia Nervosa vinden zichzelf niet mool, zouden graag veel magerder willen zijn en om te compenseren voor overmatige voedselinname tijdens bijvoorbeeld eetbuien wordt er aan de lijn gedaan en in de meeste gevallen ook veelvuldig gebraakt en laxantia gebruikt. De zelfwaardering van patiënten met Bulimia Nervosa is te sterk afhankelijk van de opvattingen die zij hebben over hun eigen lichaamsvormen en gewicht. Overigens hebben patiënten met Bulimia Nervosa meestal een normaal gewicht.

Onder de eetstoornissen NAO vallen verschillende groepen mensen met eetproblemen of eetstoornissen. Bijvoorbeeld degenen die net niet voldoen aan de diagnostische criteria van beide andere stoornissen, zoals iemand die alle klinische kenmerken van Anorexia Nervosa vertoont maar niet voldoende afgevallen is om de diagnose Anorexia Nervosa te kunnen stellen. Ook de Eetbuistoornis (Binge Eating Disorder) valt in deze categorie. De eetbuistoornis is een vrij recent onderkende eetstoornis die zich kenmerkt door herhaaldelijk optredende

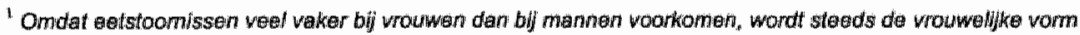

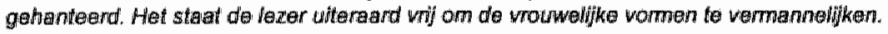


eetbuien en waarbij het betrokkene niet lukt om te compenseren voor het overeten, met als gevolg dat de meeste mensen die last hebben van deze eetstoornis meestal ook overgewicht hebben.

Anorexia Nervosa komt bij ongeveer 0,5 tot $1 \%$ van de meisjes en jonge vrouwen tussen de 15 en 30 jaar voor, terwijl Bulimia Nervosa 1 tot $3 \%$ van deze groep treft (APA, 1994). In Nederland zouden er per jaar ongeveer 30.000 meisjes en jonge vrouwen lijden aan Anorexia- of Bulimia Nervosa (SEN, 1998). Bij jongens en mannen zijn deze eetstoornissen een veel zeldzamer verschijnsel, ongeveer 5 tot $10 \%$ van het aantal gevallen is van het mannelijke geslacht. De eetbuistoomis komt voor bij 1 tot $4 \%$ van de hele populatie, in Nederland komt dit neer op enkele honderdduizenden mensen, en dit zijn met name mensen die behandeling zoeken voor hun overgewicht. Vrouwen hebben er twee keer zo vaak last van als mannen. Hoe vaak de andere eetstoornissen NAO voorkomen is niet bekend.

Naast de eerder genoemde specifieke eetpathologie hebben mensen met eetstoornissen vaker dan normaal last van bijkomende depressieve gevoelens, angsten, persoonlijkheidsstoornissen en een lage zelfwaardering. De angsten en depressieve gevoelens zijn in de meeste gevallen een gevolg van de eetproblematiek. Dat het ernstige stoornissen zijn adstrueren de cijfers over mortaliteit: het aantal patiënten dat sterft aan anorexia nervosa ligt in Nederland en Duitsland 
rond de $6 \%$ van het aantal gevallen (Hoeken \& Hook, 1999; Fichter \& Quadflieg, 1999).

Eetstoornissen voltrekken zich dus volgens typische patronen en zijn overwegend samen te vatten in een drietal terugkerende kenmerken: abnormaal eetgedrag, een negatief lichaamsbeeld en al dan niet succesvolle pogingen om gewicht te verliezen.

\section{Over het ontstaan en voortbestaan}

Tussen het begin van de jaren " 80 en nu zijn er over het onderwerp eetstoornissen duizenden Engelstalige publicaties in wetenschappelijke tijdschriften verschenen. $U$ zou nu dus kunnen denken dat we intussen wel weten hoe het komt dat sommige mensen een eetstoomis hebben. Niets is echter minder waar. Ik heb niet precies gedocumenteerd waar al die duizenden publicaties over gaan, maar sla het meest recente handboek over eetstoornissen en obesitas (Brownell \& Fairburn, 1995) open en merk op dat er van de 101 hoofdstukken welgeteld 8 , dat is nog geen $8 \%$, over oorzaken of instandhoudende mechanismen gaan. De rest gaat over verschijningsvormen en zaken als de regulatie van normaal eetgedrag en gewicht, het meten van voedselinname en energieverbruik, klassificatie, geschiedenis, epidemiologie, medische complicaties en behandeling. Het boek is geredigeerd door twee wereldbekende experts en wordt aangekondigd als de state of the art en $i k$ vrees dat het dat inderdaad is. 
Wat ik u vanmiddag duidelijk wil maken en wat ook de rode draad van mijn betoog zal zijn, is dat niets zo praktisch is als een goede theorie. Het zal $\mathrm{u}$ in de loop van de middag opvallen dat de effectiviteit van behandelingen voor met name Anorexia Nervosa gering is. Dat is niet zo gek als $u$ bedenkt dat we helemaal niet weten hoe het komt dat sommige mensen Anorexia Nervosa hebben. Een behandeling krijgt dan al snel de kenmerken van het schieten met losse flodders, misschien is het raak en misschien ook niet. En begrijpt u mij goed, dit is geen verwijt aan behandelaars. Die doen hun best en handelen naar beste eer en geweten. Maar zonder goede theorie komen ze niet ver.

Onderzoekers en makers van beleid zouden dit op hun fatsoen moeten trekken. Modellen over het ontstaan en voortbestaan van eetstoornissen moeten bedacht en getoetst worden en daar moet veel gelegenheid voor zijn. Daarom zijn de huidige ontwikkelingen hoopvol: het aardige van professor worden is dat juist ik mezelf vandaag de opdracht mag geven om veel tijd te gaan steken in de ontwikkeling en toetsing van die modellen. Het is ook mooi en verstandig dat de beleidsmakers van de Universiteit Maastricht met de installering van deze leerstoel de intentie uitspreken dat ze dit soort onderzoek belangrijk vinden.

Het gebrek aan kennis over het ontstaan en voortbestaan van eetstoomissen is voor veel experts aanleiding om te beweren - en ook daadwerkelijk te geloven - dat eetstoornissen een onuitputtelijk aantal wisselende oorzaken hebben. Dit zogenaamde multicausaliteitsmodel is gemeengoed geworden en figureert nog steeds als het belangrijkste 
"etiologische model" in de eetliteratuur (Bloks, van Furth \& Hoek, 1999; Brownell \& Fairburn, 1995; Garner, 1997; SEN, 1998; Spaans, 1998; Vanderlinden, 2000).

Het model bestaat in feite uit niets meer en niets minder dan een holistische matrix waarin de meest abstracte causale en onderhoudende factoren opgetekend zijn. Zo worden er een biologisch, psychologisch en sociaal nivo onderscheiden en daaromheen cirkelen voorbeschikkende, uitlokkende en onderhoudende factoren (zie Figuur 1).

Figuur 1: het multicausaliteitsmodel van eetstoornissen

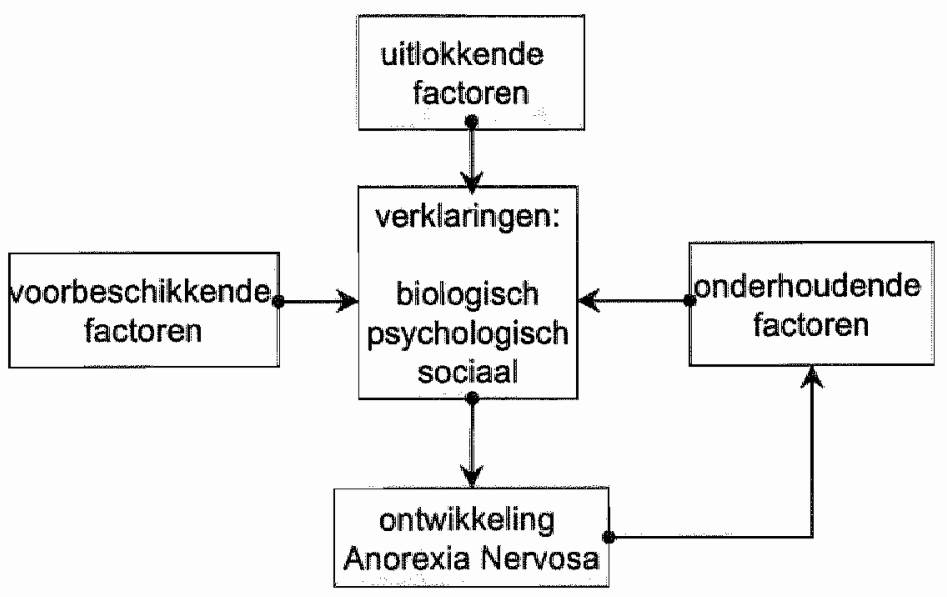

Spaans (1998, pag 44): "schema van factoren dile wan belang zilin bij het ontstaan en in stand houden van anorexia nervosa" 
Aanhangers van het multicausaliteitsmodel benadrukken het circulaire en idiosyncratische karakter van alle mogelijke interacties binnen deze biopsychosociale entiteit. Hoewel het model op het eerste gezicht een redelijke en plausibele indruk maakt, zal ik betogen dat deze multicausale benadering van eetstoornissen een verlegenheidsoplossing is die uitsluitend ad hoc verklaringen voortbrengt. Verderop zal ook aan de orde komen waarom het multicausaliteitsmodel, ondanks voor de hand liggende methodologische tekortkomingen, zich in zo'n brede populariteit mag verheugen.

Het multicausaliteitsmodel stoelt op de assumpties dat 1) eetstoornissen ontstaan uit een per individu verschillende mix van factoren en dat 2) dezelfde factoren en ook dezelfde mix van factoren bij de een wel en bij de ander niet tot een eetstoornis hoeven te leiden (Garner \& Garfinkel, 1982, p.191; Garner, 1997). Die aannames impliceren, en dat is belangwekkend, dat het nooit mogelijk is om een algemene uitspraak over het ontstaan van eetstoornissen te doen. Eetstoornissen zouden écht een wisselend spectrum van oorzaken hebben en het zou onmogelijk zijin om algemene wetten te vinden waaruit het wel of niet ontstaan van eetstoornissen kan worden afgeleid. Zo'n model genereert geen hypothesen want het reflecteert volgens haar makers de ultieme werkelijkheid. Het geloof dat er geen algemene wetten zijn die ten grondslag liggen aan het ontstaan van eetstoornissen en de ontkenning 
van het model als hypothesegenererend uitgangspunt plaatst de activiteiten van multicausalisten buiten het domein van de empirische wetenschap.

Voorspellingen vormen namelijk het voornaamste waarmerk van een empirische wetenschap. Om met de Groot (1961) te spreken: "Als ik iets weet, kan ik iets voorspellen; kan ik niets voorspellen dan weet ik niets". Vanuit het multicausaliteitsmodel valt er niets te voorspellen. Het dwingt onderzoekers om een andere dan de reductionistische richting in te slaan. Er kàn niet gezocht worden naar verklarende mechanismen want voor ieder individu is de ontstaansgrond uniek.

Gelukkig kan kennisgroei een multifactoriële denkwijze inhalen (Jansen \& Boon, 1991). We zagen het eerder bij AIDS gebeuren. Lange tijd werd er gedacht dat ook AIDS multicausaal bepaald was; allerlei factoren zouden leiden tot de ontwikkeling van AIDS. Totdat men het HIV ontdekte. Toen werd duidelijk dat besmetting met HIV de oorzaak van AIDS was.

Voor dit soort ontdekkingen is reductie meestal nodig. Niet de totale patiënt moet centraal staan in het onderzoek, ontregelde mechanismen moeten onder de loep genomen worden. Uitsluitend reductie kan de totale patiënt uiteindelijk verder helpen. Het gebeurt maar al te vaak en al te gemakkelijk dat onderzoek dat niet de totale patiënt betreft, wordt afgedaan als een niet-valide ivoren torenproduct. Daarmee wordt niet alleen deze zuivere vorm van onderzoek in diskrediet gebracht, ook de ontwikkeling van broodnodige kennis wordt in de kiem gesmoord. 


\section{Noodzakelijke en voldoende factoren}

Welke factoren zijn nu noodzakelijk en voldoende om een eetstoornis te ontwikkelen? Onderzoek naar risicofactoren vond mondjesmaat plaats en is in het merendeel van de gevallen retrospectief van aard. De Britse psychiater Fairburn (Fairburn, Welch, Doll, Davies \& O'Connor, 1997) vond, door ook een psychiatrische controlegroep in zijn onderzoek te betrekken, dat veel van de vermeende risicofactoren die in het multicausaliteitsmodel genoemd worden, niet specifiek tot eetstoornissen leiden. Daarentegen bleken onder andere pre-morbide overgewicht van de patiênt en gezinsleden die voortdurend commentaar leveren op de lichaamsvormen, het gewicht en het eetgedrag van de patiënt een specifieke rol in de ontwikkeling van eetstoornissen te spelen. Zij zouden specifiek aanzetten tot pogingen om het gewicht te verminderen en zodoende het risico op een eetstoornis vergroten. Deze bevinding staat niet op zich. Ook de onderzoeker Thompson uit Florida toonde in een groot aantal studies aan dat vrouwen met eetstoornissen in hun jeugd aanzienlijk vaker bekritiseerd werden om hun lichamelijke voorkomen dan vrouwen zonder eetstoornis.

Die bevindingen lijken belangwekkend maar de methode van onderzoek maakt dat enig voorbehoud hier op zijn plaats is. Bovengenoemde studies waren retrospectief van aard en zelfrapportage was de belangrijkste bron van informatie. Retrospectief zelfrapportage onderzoek naar risicofactoren levert gegevens op die met grote mate van waarschijnlijkheid niet betrouwbaar zijn. Patiënten hebben een 
stoomis en op het moment dat ze ongelukkig zijn wordt hen gevraagd hoe het ze vroeger verging. Hoe zwaar ze toen waren. Wat anderen toen van hun lijf vonden. Het is goed voorstelbaar dat mensen die hun lichaam verafschuwen en die zichzelf te dik vinden, ook al zijn ze uitgemergeld, denken dat ze altijd al zo'n olifantenlijf hadden en zich met terugwerkende kracht ook allemaal plagerijen rondom dat lichaam herinneren.

De recent gepubliceerde prospectieve studie van Stice (Stice, Mazotti, Krebs \& Martin, 1998) naar determinanten van lijngedrag onder scholieren is methodologisch netter en levert belangwekkende gegevens. De onderzoekers vonden dat ontevredenheid met het eigen lichaam verreweg de beste voorspeller van lijngedrag was. Dit lijkt een open deur maar is het niet. Die ontevredenheid met het lichaam hing namelijk niet sterk samen met een daadwerkelijk hoger gewicht en ook niet met de ervaren sociale druk om slank te zijn. Een hoger lichaamsgewicht en de gepercipieerde druk om slank te zijn voorspelden het lijngedrag niet of nauwelijks. De bevindingen suggereren dat het belang dat aan het slankheidsideaal wordt gehecht en de overtuiging pre-morbide dik te zijn geweest gevolgen van het lijnen zijn, in plaats van andersom.

Dat de lichaamsontevredenheid niet gerelateerd is aan het werkelijke gewicht en slankheidsideaal, is een belangwekkende vaststelling. Deze bevinding biedt veel stof tot nadenken en onderzoek. Want hoe belangwekkend onderzoek naar risicofactoren ook kan zijn, het zegt 
verder niets over mechanismen, over hoe het komt dat mensen waarbij deze factoren een rol spelen een eetstoornis ontwikkelen. Vanaf dit moment hult bijna iedereen zich in stilzwijgen, terwijl het nu pas echt spannend gaat worden. Hoe komt het dat sommige mensen hun lichaamsgewicht als hoog percipiëren terwijl dit in werkelijkheid niet het geval is? Waarom zijn sommige mensen ontevreden over hun lichaam, ook al is er objectief gezien niets aan de hand? Wat is de precieze aard van die ontevredenheid? Hoe is die lichaamsontevredenheid te reduceren? Het is precies dit soort vragen dat op experimentele wijze, door middel van reductionistisch onderzoek, beantwoord kan worden. Dit is overigens niet alleen spannend, het heeft ook veel Nut. Als we weten hoe lets precies in elkaar steekt, dan is er vast en zeker ook iets aan te doen. Daarover meer.

Wij onderzochten het lichaamsbeeld van een groep extreme lijners waarvan een deel een subklinische eetstoornis had. Wat opviel is dat het gewicht van de groep lijners even hoog was als het gewicht van de groep niet-lijners, dat ook de verhouding tussen hun taille en heupen even groot was en dat een groot forum Maastrichtenaren de lijners aok subjectief gezien niet dikker vond ogen dan de vrouwen die niet aan de lijn deden. Zoals verwacht gaven de lijnende vrouwen zichzelf wel een veel lagere beoordeling voor hun eigen lichaam dan de niet-lijnende vrouwen. Maar wat niet werd verwacht, is dat het Maastrichtse forum dit ook deed. Daarbij haast ik me om aan te tekenen dat dit veeleer een 
academisch interessant verschil betrof dan een klinisch belangwekkend verschil. Het verschil was klein maar significant.

Dat verschil in beoordeling van de beide groepen hing niet samen met verschillen in de objectieve grootte van de lichamen. Zowel in het relatieve gewicht als in de verhouding tussen taille en heupen verschilden beide groepen niet en toch werden de lijners minder aantrekkelijk gevonden. Waarom worden lijners dan minder mooi gevonden is natuurlijk de vraag die we ons vervolgens hebben gesteld en het onderzoek dat die vraag moet beantwoorden draait nu op volle toeren. Daar kan ik dus nog niets over zeggen.

De hier gepresenteerde data suggereren in ieder geval dat de ontevredenheid over het lichaam samenhangt met een minder mooi maar zeker niet te dik lichaam. En dat die ontevredenheid met het lichaam ten onrechte op het gewicht wordt afgewenteld. Aan een lichaamsgewicht lijkt natuurlijk ook gemakkelijker iets te doen dan aan een smalle schouders, scheve knieën of kromme benen. Indien patiënten weten dat ze niet te dik zijn, hebben we te maken met een 'kronkelredenering'. Ik ben niet te dik maar wel lelijk en dus ga ik aan de lijn doen. Alsof vermageren ze van iets lelijks af kan helpen. Denken ze echt dat ze te dik zijn, en om daar achter te komen moeten we ze niet om een antwoord vragen maar bijvoorbeeld een geschikte reactietijdentaak laten uitvoeren, dan illustreert dit een logischconsistente doch foutieve redenering. Met andere woorden, we hebben het hier over cognitieve processen die aan de basis van de eetstoornis zouden kunnen liggen. Die cognitieve processen kunnen door middel 
van reductionistische experimenten heel precies in kaart gebracht worden. Zodra er een spaarzaam model geformuleerd is, kan er vervolgens nagegaan worden of experimentele manipulatie van de processen die verantwoordelijk geacht worden, inderdaad veranderingen teweegbrengt in het gedrag dat we willen verklaren.

\section{Hoe zijn eetstoornissen te genezen?}

Ondanks de eerder besproken ernstige methodologische tekortkomingen is de multicausaliteitsvisie ook bij werkers in het veld gemeengoed geworden. Die populariteit wordt begrijpelijk indien wordt gepostuleerd dat het multicausaliteitsmodel tevens steunt op een doorgaans verzwegen assumptie. Die assumptie luidt dat elke mens uniek is. In de klinische praktijk wordt, onder invloed van de multicausaliteitsvisie, het belang van eenmalige processen in unieke individuen onderstreept. Het model laat onderzoekers en klinici de vrijheid om eetpathologie te verklaren uit allerlei processen die men op deze unieke patiënt van toepassing acht.

Een belangwekkende vraag is of uit een multicausale pathogenese van eetstoornissen ook logisch volgt dat een strikt individuele therapie onatwendbaar is. Stel dát de eetstoornis een concrete unieke gebeurtenis betreft die niet volgens algemene principes verklaard kan worden, kunnen er dan over de behandeling van die eetstoornis ook geen algemene en empirische uitspraken gedaan worden? Multicausalisten menen van niet. Een eenvoudig voorbeeld uit de geneeskunde toont dat dit een misvatting is: stel, twee individuen breken 
op geheel verschillende wijze het linkerbeen. Persoon A gleed tijdens de marathon uit over een bananenschil, persoon $B$ kwam stomdronken uit de kroeg en struikelde over de stoeprand. Persoon A en B zijn zeer verschillend: $A$ is sportief, heeft zwarte krullen en tuurt met bruine kijkers de wereld in, $B$ is een blonde vlegel met waterblauwe ogen. Toch luidt het advies van de medische professie in beide unieke gevallen: een spalk en wat gips. Kennelijk zijn de precieze oorzaak van de beenbreuk (struikelen over een stoeprand of uitglijden over een bananeschil) en individuele kenmerken (een donkere sportman of een blonde dronkelap) niet van belang voor een empirische uitspraak over de beste behandeling. Ook in geval van eetstoornissen geldt dat onbekendheid met de preciese oorzaak ervan geen argument is om geen uitspraken over de beste behandeling te doen. Het behandeladvies kan altijd aan empirische criteria onderhevig zijn: ook zonder kennis van de preciese oorzaak van eetstoornissen is advies over de meest succesvolle vorm van therapie mogelijk. Laten we eens kijken wat de stand van zaken is.

De gebruikelijke behandeling voor anorexia nervosa is tegenwoordig meestal veelzijdig van opzet. Naast dat er gestreefd wordt naar gewichtstoename, worden patiënten geconfronteerd met hun eigen lichaam in spiegel en op video. Ze leren emoties bespreken, krijgen psycho-educatie, creatieve therapie, danstherapie interoceptieve waarnemingstherapie, lichaamsgerichte therapie, er wordt gewerkt aan een toename van de zelfwaardering en een verbetering van sociale vaardigheden en tot slot vindt er ook nog terugvalpreventie plaats 
(Fichter \& Quadflieg, 1999; Bloks, van Furth \& Hoek, 1999;

Vanderlinden, 2000). Duitse onderzoekers inventariseerden het effect van een dergelijke breedspectrum of multimodale integraalbehandeling (Fichter \& Quadflleg, 1999). De studie voldoet bij lange na niet aan de methodologische eisen die er tegenwoordig aan outcome studies gesteld worden. Er was bijvoorbeeld geen manipulatiecheck, er werden geen controlegroepen gebruikt en er werd niets gestandaardiseerd.

Desandanks biedt de Duitse inventarisatie wel enige beschrijvende informatie. Precies 103 patiënten met Anorexia Nervosa zaten gemiddeld 120 dagen intern in een groot medisch-psychologisch ziekenhuis en ondergingen de 'breedspectrumbehandeling' zoals hierboven beschreven. Zes jaar na de behandeling werden de patiënten uitgebreid gemeten. Overigens bleek dat $65 \%$ van de patiënten in die tussenliggende 6 jaar gemiddeld nog eens 176 dagen intern in een ander ziekenhuis voor de eetstoornis behandeld was. Deze patiënten hadden dus gemiddeld een interne behandeling van 296 dagen achter de rug, dat is een opname van bijna 10 maanden.

Zes jaar na de behandeling bleek $55 \%$ officieel geen eetstoornis meer te hebben. Zij vertoonden nog wel veel symptomen van eetstoornissen, zo schrijven de auteurs, en die opmerking wordt ondersteund door het gegeven dat het gewicht van de patiënten, ondanks flinke verbetering, nog altijd veel lager dan normaal was.

Zes procent van de patiënten was overleden. Vat ik de resultaten van zo'n multimodale en integrale totaalbehandeling in het kort samen, dan 
zijn de resultaten op lange termijn dus zeer matig, ondanks dat kosten noch moeite worden gespaard.

Een eerste neiging die velen van u ongetwijfeld niet kunnen onderdrukken is te denken dat het hier wel om een heel ingewikkelde stoornis of buitengewoon moeilijke patiënten zal gaan. Dat eetstoornissen bijna niet te behandelen zijn en dat lemand een eetstoornis voor het leven heeft. $U$ bevindt zich in goed gezelschap, vele deskundigen denken dit ook.

En misschien hebben u en die deskundigen wel gelijk. Maar voordat u van mij gelijk krijgt, zou ik eerst willen nagaan of het gebrek aan goede behandelmethodes een rol kan spelen bij het bescheiden succes van de behandelingen. Ik bedoel, je kunt een voetbalwedstrijd verliezen omdat de bal te glad is, het gras te lang en de doelpalen te krom, maar het verlies kan ook het gevolg zijn van een gebrek aan goede spelers.

De behandeling die de Duitsers beschreven is een vrij gangbare, ook in Nederland. Het is een omvattende en dure behandeling en het is niet duidelijk of hij effect heeft, want hoeveel procent geneest er bijvoorbeeld spontaan binnen 6 jaar. Het is ook niet duidelijk waar de bescheiden successen aan te danken zijn; welke onderdelen van de behandeling zouden waarom effect kunnen hebben. Ook niet onbelangrijk is de vraag welke elementen uit de behandeling contraproductief zijn. Wat gebeurt er bijvoorbeeld tijdens de confrontatie met het eigen lichaam voor de spiegel? Leidt dit tot een vermindering van de walging van het eigen 
lichaam of intensiveert die afkeer juist? Is het een vorm van exposure of worden cognities geherstructureerd? Welke cognities en hoe precies? Een retorische vraag die ik zou willen stellen is of het niet zinvol is om, in het belang van de patiënten, de effecten van dergelijke ingrijpende manipulaties eerst goed en geïsoleerd te bestuderen, in bijvoorbeeld het gedragslaboratorium op analoge groepen, voordat ze zonder enige kennis van de gevolgen op patiënten worden toegepast.

Een jaar of twintig jaar terug dacht men ook dat Bulimia Nervosa niet te behandelen was. Nadien heeft de ontwikkeling van zowel etiologische modellen als protocollen een hoge vlucht genomen en op dit moment geneest twee derde van de patiënten met Bulimia Nervosa na een kortdurende behandeling. Een twintigtal goed gecontroleerde en grootschalige studies uit verschillende landen en door verschillende onderzoeksgroepen toont eenduidig aan dat cognitieve gedragstherapie momenteel de meest effectieve vorm van behandeling voor bulimia nervosa is (Whittal, Agras \& Gould, 1999; Wilson, 1996; Wilson, 1999). Cognitieve gedragstherapie is gericht op zowel de verandering van disfunctionele denkpatronen als de verandering van gedrag. Gemiddeld leidt cognitieve gedragstherapie tot $80 \%$ reductie van de eetbuien en om en nabij de $60 \%$ van de patiënten heeft in het geheel geen eetbuien meer (Wilson, 1996; Wilson, 1999). Cognities omtrent eetgedrag, lichaamsvormen en lichaamsgewicht zijn na afloop van cognitieve gedragstherapie minder disfunctioneel en het eetpatroon is normaler, er wordt tussen de eetbuien door meer gegeten en minder gelijnd. De 
zelfwardering gaat bil de meeste patienten omhoog, depressies klaren op, persoonilikheidsstoornissen verdwinen of interfereren minder met het dagelijkse leven en ook het sociaal tunctioneren verbetert Wilson, Fairbum \& Agras, 1997). Kortom, hel likt erop alsof Bulimia Nervosa voor behandelaars geen probleem meer is.

Dit is natuurlik niet helemaal het geval. Hoewel er en finke eetbuireductie en hoge abstinentiepercentages bereikt worden bleek dat 6 jaar na de behandeling $37 \%$ van de patiènten nog steeds een eetstoomis had: $20 \%$ voldeed nog aan de diagnostische criteria van bulimia nervosa en $17 \%$ had inmiddels een eetstoomis NAO. Dus 6 jaar na de cognitieve gedragstherapie ziln grofweg 4 van de 6 patiênten genezen, 1 heeft er nog Bulimia Nervosa en 1 heeft er een wat minder emstige eetstcornis (Fairbum et at., 1995).

Deze laatste, wat minder rooskleurige cjfers laten onverlet dat cognitieve gedragstheraple wel het beste is dat mensen met bulmia nervosa geboden kan worden. Er is momenteel geen betere therapie voorhanden. Dus cognitieve gedragstherapie zou voor patiënten met bulimia nervosa de standaardbehandeling moeten zijn. Maar onderzoekers moeten zich beraden: Hoe kan de effectiviteit van de behandeling worden vergroot? $\mathrm{Er}$ is tamelijk veel room for improvement.

Een primaire reactie zou kunnen zijn om de behandeling ingewikkelder en langer te maken, met name voor de ernstigste patiënten, maar dat lijkt mij nu juist niet de beste strategie omdat elk empirisch argument 
daarvoor ontbreekt. Het is niet aangetoond dat lange omvattende behandelingen voor bepaalde patiënten beter zijn dan korte specifiekere behandelingen. We hebben dan ook helemaal geen idee waarom sommige patiënten geen baat hebben bij de gebruikelijke cognitieve gedragstherapie: voorspellers van therapiefalen zijn niet gevonden. Wel duidelijk is dat succes van een behandeling niets met de duur of ernst van de stoornis te maken heeft (Schoemaker, 1998; Schoemaker et al., in press; Wilson, 1996). Wellicht moeten we er eerst achter zien te komen wát we precies moeten behandelen en daar dan een gerichte therapie voor bedenken.

Want wat opvalt is dat ook de bij Bulimia Nervosa gebruikelijke cognitieve gedragstherapie uit een flink aantal behandelcomponenten bestaat, veel meer dan de term cognitieve gedragstherapie zou doen vermoeden. De cognitieve gedragstherapie zoals die oorspronkelijk door de Britse psychiater Fairburn ontwikkeld en beschreven is (zie bijvoorbeeld Fairburn, Marcus \& Wilson, 1993) blijkt in feite óók een breedspectrum behandeling te zijn, maar dan een die welomschreven en geprotocolleerd is. Het is een mix van allerlei technieken: er wordt in dagboeken geregistreerd, er worden zelfcontroletechnieken aangeleerd, er wordt psycho-educatie gegeven, er wordt aan exposure gedaan, dieet management, cognitieve herstructurering, het probleemoplossende vermogen wordt getraind, er worden ontspanningsoefeningen gedaan, assertiviteitstraining, interpersoonlijke training, coping strategieën worden aangeleerd en er vindt terugvalpreventie plaats. In korte tijd, de 
behandeling beslaat gewoonlijk 19 sessies van een uur, hebben patiënten dus een hoop te doen. Net als bij de behandeling van Anorexia Nervosa weten we niet welke componenten van dit multiprogramma effectief, noodzakelijk, voldoende, overbodig of contraproductief zijn.

Welke technieken uit de cognitieve gedragstherapie volgen dwingend uit etiologische modellen over de stoornis? In feite alleen de cognitieve herstructurering en dieet management. Cognitieve herstructurering is een goede interventie om de cognitieve processen rondom de afkeer van het lichaam aan te pakken. Dieet management probeert het lijnen tegen te gaan, maar tevens is het een procedure die de klassiek geconditioneerde drang om te eten vermindert, want mensen introduceren eetbuivoedsel in hun gewone dieet. Misschien is de behandeling wel effectief vanwege een van deze twee interventies. We namen in nauwe samenwerking met het geacademiseerde eetteam van de RIAGG Maastricht de proef op de som. Patiënten met Bulimia Nervosa werden volgens het lot toebedeeld aan een van de volgende kortdurende pure en poliklinische behandelingen: cognitieve therapie, dieet management of cue exposure met responspreventie. In totaal besloeg de behandeling voor iedere patiënt slechts 15 uur en elke patiënt werd met alleen die ene techniek behandeld. lk kan u iets mielden over de voorlopige resultaten bij 41 patiënten met bulimia nervosa. Voorlopig omdat er nog niet voldoende patiënten onderzocht zijn en omdat nog lang niet alle data geanalyseerd zijn. Vooropgemerkt bleek dat onze patiëntengroep even ernstig was als de groep patiënten uit de 
psychiatrische kliniek in Oxford. Omdat onze groep nog klein is, 41 patiënten verdeeld over 3 condities, en omdat de resultaten tussen de condities niet verschilden, volsta ik met de resultaten van de groep als geheel. Bij de follow-up een jaar na deze kortdurende therapie, bleek het aantal eetbuien met $87 \%$ gereduceerd en $61 \%$ van de patiënten was eetbuivrij. Niet alleen het eetgedrag was verbeterd, ook cognities, stemming, zelfwaardering en sociaal functioneren waren verbeterd. Wat suggereren deze voorlopige gegevens? Zij suggereren dat een therapie die vele elementen omvat niet noodzakelijk is en dat er kan worden volstaan met een enkele effectieve techniek die geënt is op een spaarzaam model over het mechanisme dat de eetstoornis in stand houdt. Met zo'n korte enkelvoudige therapie worden vergelijkbare resultaten geboekt als met de langere omvattende therapie. Merkt $u$ op dat die modellen over instandhoudende mechanismen nog voor veel verbetering vatbaar zijn. Het zou me niets verbazen als een nog valider model zou leiden tot nog spaarzamere en effectievere interventies.

Al met al kan er een heldere conclusie getrokken worden: een primaire reactie op ingewikkelde problemen is om er een ingewikkelde behandeling op los te laten. Tegen de verwachting in blijkt een lange en omvattende behandeling niet zonder meer effectief te zijn bij de bestrijding van moeilijke problemen. Spaarzame modellen over instandhoudende mechanismen daarentegen, dicteren heel gerichte interventies die noodzakeilijk en voldoende zouden moeten zijn om thet 
mechanisme te tekkelen. Enkele voorlopige bevindingen suggereren inderdaad dat dit zo werkt.

\section{De dagelijkse praktijk}

In de dagelijkse praktijk worden er allerlei vormen van behandeling losgelaten op mensen met eetstoornissen, van psycho-analyse tot aan multimodale totaalpakketten. Recent Amerikaans onderzoek (Mussell, Crosby, Crow, Knopke, Peterson, Wonderlich \& Mitchell, 2000) toont dalt slechts 1/3 van de hulpverieners die patiënten met Bulimía Nervosa behandelen iets aan cognitieve gedragstherapie zegt te doen, terwijl tal van goed gecontroleerde empirische gegevens er toch op wijzen dat dit momenteel de voorkeursbehandeling voor Bulimia Nervosa is. De meeste ondervraagde psychotherapeuten gebruiken "eclectische methoden", hetgeen een eufemisme is voor "doen waar je zin in hebt'. Een voor de hand liggende vraag is waarom patiènten met Bulimia Nervosa in de dagelijkse praktijk van de hulpverlening niet als vanzelfsprekend met cognitieve gedragstherapie behandeld worden Waarom vinden empirisch-gevalideerde behandelingen zo traag hun weg naar de dagelijkse klinische praktijk? Daar zijn verschillende redenen voor aan te voeren (Persons, 1995).

Een eerste reden is dat psychotherapeuten veel te weinig getraind worden in effectieve methoden en veel te veel in methoden die niet effectief bleken te zijn. De Amerikaanse APA Task Force die gaat over de promotie en verspreiding van psychologische technieken, 
analyseerde in 1993 doctoraalprogramma's voor studenten klinische psychologie. In totaal werd er in minder dan de helft (46\%) van de opleidingen aandacht besteed aan gevalideerde behandelingen. Er waren APA geaccrediteerde opleidingen die helemaal geen training in empirisch gevalideerde behandelingen gaven. Van de Amerikaanse psychotherapeuten die Bulimia Nervosa behandelen, behandelt 1/3 met cognitieve gedragstherapie en slechts $65 \%$ van de mensen die cognitieve gedragstherapie geven is ooit getraind in deze vorm van behandeling. De Task Force vond ook dat $20 \%$ tot $74 \%$ van de opleidingen en supervisies behandelmethodes betrof die in het geheel niet effectief zijn. Kortom: er wordt over het algemeen slecht opgeleid. Therapeuten worden getraind om behandelingen uit te voeren die niet effectief zijn en ze worden niet getraind in behandelingen die wel effectief zijn.

De kwaliteit van de psychotherapie-opleidingen zou beter bewaakt moeten worden, zodat voor stoornissen waarvan dit bekend is uitsluitend de empirisch gevalideerde behandelmethoden onderwezen worden. En uiteraard zou het NIP alleen die vormen van behandeling mogen accrediteren die empirisch gevalideerd zijn. Omdat het veld zich ontwikkelt zouden psychotherapeuten verplicht moeten worden, en genoeg tijd moeten krijgen, om bijscholing in empirisch gevalideerde behandelingen te volgen of zelf te geven.

Dat psychotherapeuten de in de vakpers gepubliceerde outcome studies niet lezen en zich vaak helemaal niet bewust zijn van de empirische 
status van hun favoriete behandeling, is begrijpelijk. Hun hele week is volgepland met patiëntcontacten en teamvergaderingen. Het zou goed zijn als het bijhouden van de literatuur, het bijwonen van congressen, het volgen en ook het geven van workshops en trainingen ook tot de taakstelling van psychotherapeuten zou gaan behoren.

Onderzoekers zouden ook beter hun best kunnen doen door belangrijke bevindingen over effectieve behandelingen op toegankelijke wijze te verspreiden. De farmaceutische industrie besteedt miljoenen aan de verspreiding van kennis over nieuw ontwikkelde pillen, psychologen doen vrijwel niets met nieuw ontwikkelde en effectieve behandelprotocollen (Barlow, 1994 in Persons, 1995). Er zijn verschillende Nederlandstalige tijdschriften en reeksen die het publiceren van leesbare protocollen, handleidingen en belangwekkende wetenschappelijke bevindingen op toegankelijke wijze hoog in het vaandel dragen. Dergelijke publicaties zouden best wat meer aanzien kunnen krijgen en lezers moeten er van op aan kunnen dat die publicaties van hoge standaard zijn, dus dat hetgeen er geschreven is ook daadwerkelijk empirische credits heeft.

Een laatste belangrijke reden waarom de dagelijkse praktijk zo weinig gericht is op aantoonbare effectiviteit is dat veel psychotherapeuten sceptisch zijn en denken dat ze zelf een ander soort patiënten behandelen als de patiënten waarover de onderzoeker publiceerde. Het verwijt van sommige behandelaars aan onderzoekers is dat onderzoekers hun patiënten zouden selecteren en zodoende de minst 
ernstige patiënten overhouden terwijl de echt moeilijke gevallen de dagelijkse praktijk bevolken. En daar zou zo'n behandelprotocol toch veel te eenvoudig voor zijn. Voor die moeilijkere patiënten zou het absoluut nodig zijn om de behandeling zo veel mogelijk aan de individuele cliënt aan te passen. $\mathrm{k}$ ben geneigd om hier het prachtige onderzoek van de Duitsers Schulte, Künzel, Pepping en SchulteBahrenberg (1992) aan te halen. Deze Duitsers toetsten de hypothese dat een therapie op maat, dus aangepast aan het individu, beter is dan een algemeen behandelprotocol. 120 mensen met een angststoornis werden behandeld door 28 ervaren therapeuten. De experimentele groep $(n=40)$ kreeg een therapie op maat: de behandeling werd gebaseerd op de individuele probleemanalyse van de patiènt en de (ervaren) therapeut mocht zich bedienen van alle technieken die hij voor deze patiënt goed achtte. De eerste controlegroep $(n=40)$ werd volgens protocol behandeld. De therapie werd beschreven in een handleiding met duidelijke instructies over wat er gedaan moest worden (exposure in vivo \& cognitieve herstructurering) en wanneer dat moest gebeuren. De behandeling was voor alle patiënten in deze groep gelijk en stond dus los van individuele bijzonderheden. De tweede controlegroep, de zogenaamde yoked control group, kreeg een therapie op maat van een ander. Elke patiënt uit de yoked control groep kreeg net zo'n behandeling als een willekeurig individu uit de experimentele groep: de behandeling was dus op maat, maar op het lijf van lemand anders geschreven. 
$\mathrm{Na}$ de protocollaire behandeling bleek $67 \%$ van de patienten geheel of grotendeels genezen, na de individuele therapie op maat was dat $39 \%$ en de therapie op maat van een ander was succesvol in $44 \%$ van de gevallen. Omdat het genezingspercentage in beide 'maatgroepen' ongeveer even groot was kan geconcludeerd worden dat maatwerk niet van belang is voor het succes van een therapie: of iemand nu volgens zijn eigen probleemanalyse of die van zijn buurman behandeld wordt, het maakt geen verschil. De standaard exposure behandeling bleek het best en exposure bleek overigens ook de beste voorspeller van succes in de therapieën op maat (sommige envaren therapeuten achtten exposure bij een maatwerkpatiënt geïndiceerd).

Het ging hier om representatieve patiënten en ervaren therapeuten die mochten doen wat ze wilden. Toch bleken de therapieen die de therapeuten intuitief geschikt achtten minder goed dan de protocollaire standaardtherapie die voortvloeide uit een model over mechanismen die angststoornissen in stand houden. $\mathrm{Er}$ is geen enkele reden te bedenken waarom deze bevindingen niet generaliseerbaar zouden zijn naar de behandeling van eetstoornissen.

\section{Zijn eetstoornissen te voorkomen?}

Deskundigen in het veld en medewerkers van het ministerie redeneren dat eetstoornissen zo vroeg mogelijk ontdekt moeten worden, zodat patiënten vroeg behandeld kunnen worden en er daardoor meer kans is dat ze genezen. Ook dit klinkt redelijk en plausibel, maar is het ook zo? 
In een uitmuntend betoog toonde Schoemaker (1998) aan dat secundaire preventie van eetstoornissen om verschillende redenen weinig zin heeft. Allereerst gaat het bij eetstoornissen om hele kleine aantallen patiënten. Juist omdat de prevalentie zo laag is en omdat we nauwelijks iets weten van risicofactoren, moeten er grote bevolkingsgroepen afgezocht worden om enkele gevalien te ontdekken. Maar dat is nog niet eens het grootste probleem. Preventie vereist dat gevallen vroegtijdig ontdekt kunnen worden, en daar zit hem bij eetstoornissen nu juist de kneep. Degenen die risico lopen, lijken zich massaal te onttrekken aan screeningsonderzoek. Verschillende studies tonen dat juist een hoog percentage van degenen die tijdens het onderzoek van verdere deelname afzagen, een eetstoornis bleek te hebben. De gevallen die gezocht worden ontkennen dat ze ziek zijn of ze schamen zich er ernstig voor en doen in ieder geval niet meer mee aan het onderzoek. Gevallen die tijdens screening opvallen en wel benaderbaar zijn, zijn meestal al in behandeling of weigeren behandeling. In die gevallen levert screening dus ook niets op, want er wordt niet eerder behandeld dan wanneer men zich spontaan zou melden.

Gevallen vroegtijdig opsporen is arbeidsintensief, moeizaam en duur. Dit zijn echter geen redenen om het niet te doen. De reden om gevallen niet vroegtijdig op te sporen is dat het helemaal nooit bewezen is dat vroegtijdige behandeling van Anorexia Nervosa en Bulimia Nervosa tot betere behandelresultaten zou leiden dan ingrijpen op een later moment (Schoemaker, 1998; Schoemaker, Reas, Williamson \& Zipfel, in press). 
Proberen we de eetstoornis een stap voor te zijn dan hebben we het over primaire preventie. Door voorlichting aan risicogroepen te geven probeert men te voorkomen dat een eetstoornis optreedt. Er zijn in verschillende landen nogal wat educatieve programma's voor scholen ontwikkeld. Dit betekent dat er op lagere en middelbare scholen les gegeven wordt over het slankheidsideaal in de westerse cultuur en de invloed daarvan op vrouwen, de puberteit en de lichamelijke veranderingen die zich daarin voltrekken, over lijnen en vermageren, over kenmerken van eetstoorissen, de gevolgen ervan, mogelijkheden binnen de hulpverlening, enzovoort. De aanname van de preventiewerkers is dat kennis over bovengenoemde onderwerpen de neiging tot lijnen en de prevalentie van eetstoornissen onder de doelgroep zal reduceren. Ook op 1250 Nederlandse scholen wordt zo'n programma gebruikt (Noordenbos, 1999). De effecten die dit programma heeft, werden echter nooit gedocumenteerd. Een recente studie uit Engeland suggereert dat dergelijke programma's wel eens contraproductief zouden kunnen werken. In die studie werd vastgesteld dat de kennis over lijnen en eetstoornissen inderdaad groter is na de interventie en dat het lijngedrag in eerste instantie verminderde. Maar een follow-up na 6 maanden toonde dat op dat moment het lijngedrag aanzienlijk was toegenomen. Zij die het programma hadden gevolgd deden juist meer aan de lijn dan zij die het programma niet hadden gevolgd en ook maakten ze zich meer zorgen over hun gewicht (Carter, Stewart, Dunn \& Fairburn, 1997). Kennis hoeft dus nlet te beschermen, integendeel. Primaire preventieprogramma's kunnen contra-productief zijn. Het is 
eigenlijk te gek voor woorden dat er geen empirisch onderzoek naar de effecten van dergelijke programma's wordt gedaan, nog vóórdat ze op grote schaal ingevoerd worden. Dergelijk onderzoek verplicht stellen zou een goede preventieve maatregel zijn.

\section{Het huidige beleid van het ministerie van VWS}

Het ministerie van WWS heeft het gelukkig goed met de eetstoornissen voor. Minister Borst ziet de wachtlijsten als voornaamste knelpunt in de zorg voor patiënten met eetstoornissen. Gemiddeld moeten patiënten met een eetstoornis 3,6 maanden wachten voordat zij klinisch behandeld kunnen worden en dit kan te lang zijn als het gaat om ernstige en soms levensbedreigende situaties. Daarom heeft zij de afgelopen jaren een aantal centra aangewezen die gespecialiseerd zijn in de behandeling van eetstoornissen. Daarnaast is er het landelijk topreferente centrum "De Ursula" dat de extra moeilijke en ernstige gevallen behandelt en binnenkort wordt er ook nog een kenniscentrum eetstoornissen geinstalleerd.

In tegenstelling tot wat sommige lezers lazen in het interview dat Wammes Bos met mij hield en dat een maand of negen terug werd gepubliceerd in het NRC, ben ik - uiteraard zou ik zeggen - vóór ruim voldoende behandelfaciliteiten en vóór hele goede behandeling van eetstoornissen. Ik denk alleen dat er op beleidsniveau, in Den Haag dus, twee strategisch onhandige manoeurres plaatsvonden. 
De eerste tamelijk onhandige zet is geweest dat de minister het paard achter in plaats van voor de wagen heeft gespannen. Het is niet efficiënt om al het beschikbare geld te steken in verruiming van het behandelaanbod, zolang er nog geen effectieve behandelingen zijn. De files achter de wagen zullen langer en langer worden, voortdurend sluiten nieuwe patiënten zich aan. En hoewel het niet uit te sluiten is dat de wagen zo ook vooruitkomt, is de werkwijze niet erg handig en de doorstroom zal op zijn minst niet vlot verlopen. Het zal u vanmiddag duidelijk geworden zijn dat er een goede theorie moet komen over het mechanisme dat eetstoomissen in stand houdt. Weten we hoe een eetstoornis ontstaat of waarom hij blijft bestaan, dan ligt de effectieve behandeling als het ware voor het oprapen. Helaas zijn ook de criteria waar het beoogde kenniscentrum aan moet voldoen voornamelijk klinisch en educatief van aard, zodat er beter gesproken zou kunnen worden van nog een zorgcentrum erbij.

De tweede strategisch onhandige manoeuvre betreft de misvatting dat selectie en specialisatie van een zevental behandelklinieken het aanbod aan effectieve behandelingen groter maakt. Ik spreek de verwachting uit dat het aanbod uiteindelijk alleen maar kleiner wordt. Want wat is het geval? Door klinieken in de behandeling van eetstoornissen te specialiseren, neigen behandelaars op bijvoorbeeld een RIAGG ertoe zich niet meer te bekwamen in de behandeling van eetstoornissen. De aanwezigheid van een gespecialiseerde kliniek garandeert immers een goede behandeling door gespecialiseerde behandelaars, dus verwijst de 
RIAGG therapeut elke patiënt zo snel als hij kan door naar die gespeclaliseerde kliniek in de buurt. Dat de wachtlijsten daardoor weer langer worden en het lijkt alsof er onvoldoende behandelcapaciteit is, staat buiten kijf. Eerder meldde ik al dat training van psychotherapeuten in RIAGGs en andere ambulante psychotherapiepraktijken van groot belang is. Minister Borst had er goed aan gedaan als zij veel geld had gestoken in een breed aanbod aan workshops, trainingen, opleidingen en supervisies in de cognitieve gedragstherapie voor eetstoomissen. Juist door heel veel psychotherapeuten te trainen wordt het behandelaanbod vele malen vergroot.

Daarnaast worden veel vrouwen met eetstoornissen aan de poort van een gespecialiseerde kliniek, overigens wederom naar beste eer en geweten van de behandelaars, veel sneller gehospitaliseerd dan vrouwen die zich aanmelden bij een niet-klinische insteiling. Dit suggereren gegevens die de Stuurgroep Eetstoornissen Nederland (SEN, 1998) in haar rapport presenteert en waarin we kunnen llezen dat de gespecialiseerde klinieken $26 \%$ van de patiënten met Bulimia Nervosa klinisch behandelen en $30 \%$ van hen in dagklinische behandeling neemt. Slechts $40 \%$ wordt poliklinisch behandeld (SEN, 1998). Vergelijken wij deze getallen met de cijfers van de psychiatrische universiteitskliniek in Oxford en die uit de geacademiseerde RIAGG Maastricht, dan zien wij daar een heel ander beeld. Daar wordt voor meer dan $95 \%$ van de patiënten met Bulimia Nervosa een kortdurende psychotherapie van 19 c.q. 15 uur geïndiceerd geacht. De $95 \%$ poliklinisch behandelde patiënten in Oxford en Maastricht, is bijna 2,5 
keer zoveel als de $40 \%$ van de gespecialiseerde instellingen. En de instellingen hebben niet duidelijk gemaakt dat hun behandeling effectiever is. Ook blijkt uit de gegevens die de instellingen presenteren niet dat hun patiënten ernstiger zijn dan de patiënten in Oxford of Maastricht. Hetzelfde plaatje lijkt op te gaan voor de NAO'ers, inclusief de Binge Eating Disorder. De vele bedden die in Oxford en Maastricht niet door Bulimia Nervosa patiënten en NAO'ers bezet worden, kunnen in die plaatsen geheel terecht worden aangewend voor de opname van patiënten met ernstige Anorexia Nervosa.

Dus de specialisatie van klinieken leidt enerzijds tot de neiging van ambulante behandelaars om door te verwijzen en anderzijds tot veel hogere opnameciifers. Beide ontwikkelingen suggereren dat er te weinig behandelcapaciteit is. Psychotherapeuten van buiten de gespecialiseerde klinieken zijn echter heel goed in staat om een flink deel van de patiënten te behandelen; dit levert meer bedden op voor de ernstigste patiënten en leidt tot minder hospitalisatie van andere patiënten.

We zijn bijna gekomen aan het einde van deze les. Ik heb getracht duidelijk te maken dat we nog onvoldoende weten over mechanismen die eetstoornissen in stand houden of veroorzaken. Dat is de reden waarom behandelingen voor met name anorexia nervosa nog zo weinig efficiënt en effectief zijn. Het formuleren van spaarzame modéllen over deze mechanismen en het op experimentele wijze toetsen van de 
modellen kan leiden tot gerichtere en effectievere behandelingen dan nu het geval is.

\section{Plannen}

Het is gebruikelijk om een oratie te eindigen met een reeks plannen en dankwoorden. Daar doe ik graag aan mee, want voor mij zijn de plannetjes het leukst en voor u ongetwijfeld de dankwoorden. Ook dit heeft te maken met de menselijke voorliefde voor casuïstiek in plaats van statistiek, we zagen er al eerder staaltjes van.

Wat ik van plan ben is in een paar zinnen gezegd. Veel, héél veel onderzoek doen naar mechanismen die eetstoornissen in stand houden. Spaarzame modellen bedenken en toetsen. lets anders bedenken als het model niet blijkt te kloppen. Doorwerken als het model wel blijkt te kloppen. Want dan kunnen er interventies aan gekoppeld worden. Die kunnen eerst experimenteel onderzocht worden; leidt manipulatie van het mechanisme tot intensivering of reductie van het gedrag. Is dit allemaal succesvol dan kan er een behandeling op gebaseerd worden en die moet vervolgens natuurlijk op effectiviteit getoetst worden. Ik ga dit niet in mijn eentje doen, ik doe dit graag met al mijn enthousiaste eeten drinkcollega"s, waarover later meer.

Op het gebied van het onderwijs heb ik vele missies, maar de belangrijkste is om in studenten een empirische snaar te raken en ze te helpen bij het bedenken, opzetten, uitvoeren, verwerken en interpreteren van kristalhelder en creatief onderzoek. 
Ook heb ik een maatschappelijke missie. Ik zal het belang van strategisch onderzoek, reductionistische experimentjes, blijven uitdragen totdat iedereen er gek van wordt en roept dat-ie het nu well weet. Ook zal ik mijn best blijven doen om onderzoeksbevindingen zoveel mogelijk te vertalen naar de praktijk. Dit kan bijvoorbeeld in de vorm van het schrijven van artikelen, het geven van lezingen of het organiseren van workshops en trainingen.

In feite zijn het allemaal activiteiten waar ik al jaren druk mee ben en ik kan alleen maar zeggen dat het fijn is dat ik daar nog even mee door mag gaan.

Geacht publiek, ik will $\mathrm{u}$ hartelijk danken voor uw luisterend oor. Ik heb de reputatie om tegen schenen te schoppen en ik zal dat vandaag misschien ook wel weer gedaan hebben. In dat geval is het goed om to melden dat als ik tegen schenen schop, ik dit niet uit baldadigheid doe, maar vanuit de overtuiging dat wij mensen met eetstoornissen inderdaad het beste moeten bieden dat wij ze kunnen geven.

Dat ik hier vandaag sta, heb ik te danken aan een hele hoop mensen. Enkele van die mensen wil ik met name noemen.

Hooggeleerde Kok, beste Gerjo, decaan van onze bewogen faculteit der Psychologie. Ik ben je veel dank verschuldigd voor het in mij gestelde vertrouwen en de jou zo kenmerkende kortdate acties, waarvan ook de vlotte installatie van deze bijzondere leerstoel getuigt. Ook dank ik je 
voor de prachtige onderzoekslaboratoria, die ons voor het onderzoek naar gedragsstoornissen ter beschikking staan. We zullen er ongetwiffeld de spannendste bevindingen in doen. Dat je binnenkort je eigen leerstoel "gezondheidsvoorlichting" verruilt voor een stoel in de "toegepaste psychologie" komt goed uit. Het zal je vanmiddag niet ontgaan zijn dat onze eetclub op het gebied van de toegepaste psychologie een urgente missie heeft: Ik verheug me op de samenwerking.

Ook het College van Bestuur, het College van Decanen en de Stichting Wetenschapsbeoefening van de Universiteit Maastricht dank ik voor het vertrouwen dat zij in mij hadden, hebben en hopelijk zullen behouden.

Al mijn collega's van de Faculteit der Psychologie dank ik voor het nietsaaie, bijna ruige bestaan aan de UNS40. Ik moet zeggen, ik hou gewoonlijk wel van een beetje actie in de tent, maar het wordt nu wel weer tijd om Echte Wetenschap belangrijk te gaan vinden. Het goede pad is geloof ik wel ingeslagen, maar de weg lijkt nog lang.

Een speciaal woord van dank meen ik uit te moeten spreken voor het OBP van onze faculteit. In het bijzonder noem ik de vrouwen van de secretariaten en de mannen van de onderzoekslaboratoria. Dames en heren, Jullie zijn goud waard, en dat is de reden waarschijnlijk dat ik steeds weer denk dat we te weinig Huubjes en te weinig Marja's hebben. Zonder jullie, Marja, Ellen, Anouk, Karin, Nathalie, Yvonne, Huub. 
Marcel, Johan en Ron, zonder jullie geen wetenschap. Dank jullie hartelijk.

Een wel heel bijzonder deel van mijn collega's wordt gevormd door de prille "eet- en drinkgroep". Hoewel de naam veel Bourgondisch doet vermoeden, houden we ons toch voornamelijk bezig met uit de hand gelopen eet- en drinkpatronen van anderen. Reinout, ik heb je in Amsterdam als collega leren kennen. Van collega werd je ook nog vriend en nu ben je als vriend ook weer collega geworden, in Maastricht. Samen ontwierpen wij een spiegellab dat tevens een eetcafé blijkt te zijn en veel ruimte biedt voor Belangwekkend Onderzoek met een grote $B$ en een grote $\mathrm{O}$. Ook Brigitte, Marieke, Remco, Sandra, Sjaan en binnenkort Anne en Hermien horen bij de eet- en drinkclub. Ik ben hartstikke blij met jullie allemaal en met de onderzoeksfaciliteiten die de Faculteit ons biedt. Als eters en drinkers gaan wij vast en zeker een smakelijke toekomst tegemoet, we hebben nog een hele hoop te doen.

Dan nu het beste team psychotherapeuten dat ik ken. De geacademiseerde troep van de RIAGG Maastricht. We werken al jaren samen aan onderzoek naar de behandeling van Bulimia Nervosa. Die samenwerking verloopt wat mij betreft in leder geval uitermate prettig en succesvol. Jullie zijn zeer kundige therapeuten en de behandeling van eetstoornissen door het Bulimia-team is met recht een huzarenstukje te noemen. Jullie zouden eigenlijk verplicht gesteld moeten worden om de 
kennis die je in huis hebt nog breder uit te dragen dan jullie al doen, in de tijd van de baas wel te verstaan.

Met de eetpoli van het azM en de verslavingskliniek Welland van psychiatrisch centrum Welterhof is de samenwerking op het gebied van onderzoek naar eetstoornissen en verslavingen onlangs daadwerkelijk van start gegaan. Frans Wojciechowski en Dorien Schouten zijn hierin sleutelfiguren geweest en als ik me niet vergis dan wordt het nog wel wat tussen ons. Ook met de diëtisten van het Groene Kruis werken we nauw en heel prettig samen aan de behandeling van mensen met overgewicht. Ik stel me zo voor dat we ons vanaf heden het "Onafhankelijk Kennis- en Behandelcentrum Eetstoornissen Nederland" noemen.

Studenten van de Universiteit Maastricht. We kennen geen speciale opleiding eetstoomissen en dat is maar goed ook want iedere student die geinteresseerd is in onderwijs of onderzoek op dat gebied is van harte welkom om aan de Faculteit Psychologie een keuzeblok te volgen of een stage te lopen. Velen gingen u voor en uw kwaliteiten verbazen mij steeds weer. Ik sta bekend als een strenge juf en stel mij ook tot doel om u de beste opleiding te geven die ik u kan bieden. Veel studenten die bij mij komen om onderzoek te doen zijn in eerste instantie niet zo heel erg gecharmeerd van onderzoek, en des te meer geinteresseerd in de patient met eetstoornissen. Wat doet het mij een deugd als u na verloop van tijd roept dat uw interesse in de patiënt zodanig is toegenomen dat $u$ empirisch onderzoek wilt gaan doen. 
En dan, nu ik toch bezig ben, wil ik ook nog wel even terug naar hoe het allemaal begonnen is.

Hooggeleerde van den Hout, beste Marcel, gisteren precies tien jaar geleden promoveerde ik bij je. In mijn proefschrift schreef $i k$ dat er vrijwel niets belangrijker is voor een beginnend onderzoeker dan een snuggere promotor met een niet aflatend enthousiasme voor alles wat met empirie te maken heeft. Ik zou die uitspraak nog iets willen verfijnen. Ook voor een gevorderd onderzoeker is er niets belangrijker dan een snuggere collega met een niet aflatend enthousiasme voor alles wat met vooral niet-triviale experimentele psychopathologie te maken heeft. Om die reden is het jammer dat onze wegen zich toendertijd scheidden. Maar gelukkig hebben we e-mail en zijn we weer on-line. Dat je intellektuele hartstocht zeer besmettelijk was, schreef ik toen, en dat de aandoening behoorlijk hardnekkig is, schrijf ik nu. Het is wat vreemd om iemand te bedanken voor een besmetting, maar toch: ik heb er nog steeds heel plezierig last van, probeer op mijn beurt anderen te besmetten en hoop er nooit meer van te genezen. Dank je hartelijk, en met jou natuurlijk ook heel EPP.

Lieve broers, zus, verdere familie en vrienden, het doet mij deugd om te zien dat velen van jullie er vandaag weer bij zijn. En dat terwijl lik de meesten van jullie de laatste jaren flink verwaarloosd heb. Dat jullie nu weer hier zijn suggereert dat er sprake is van een vorm van 
Onvoorwaardelijke Vriendschap. Toch vrees ik dat onvoorwaardelijke vriendschappen niet bestaan want $k$ voel me inmiddels zo schuldig als maar kan. Eigenlijk probeer ik op omslachtige wijze te zeggen: ik moet nodig eens wat terug doen. Wat ook al niet duidelijk werd is dat $i k$ dit graag en met alie liefde zal doen.

Dan nu mijn ouders. Ook bij de voorbereiding op deze oratie, dacht ik veelvuldig aan mijn vader en moeder die alweer 14 jaar geleden erg jong overieden zijn. Ze hadden hier trots op de eerste rij moeten zitten. Ik overdacht veel en vaak hoe ik ze vandaag zou bedanken, maar het lukte me niet; ik weet nog steeds niet hoe ik dat beter kan doen dan in stitte en alleen.

Lieve Lisanne, Jeroen en Asja. Wetenschap is mijn lust, jullie zijn mijn leven. Gelooft $u$ het of niet, dames en heren, het is bil ons thuis een gezellige bende. Er is altijd wel wat te doen. De meest spaarzame verklaring voor het geringe aantal vrouwen in hogere functies lijkt me dat zeer normale vrouwen met kleine kinderen aan één zware baan wel genoeg hebben, en helemaal de behoefte niet voelen om daar nog een 60-urige werkweek buitenshuis naast te draaien, want laten we het wel hebben, daar praten we natuurlijk over als het gaat om vrouwen in hogere functies. Lisanne, Jeroen en Asja, ik vrees dat jullie niet bijdragen aan mijn wetenschappelijke productiviteit, althans niet direct, maar mijn levensgeluk is op grote hoogte gestabiliseerd. En dat heeft natuurlijk niet allén met jullie te maken. Lieve lieve Fren, wat een Geluk dat ik jou toen 
tegenkwam. Je bent het allerbeste dat mil ooit overkomen is. En hoe ik je daarvoor zal bedanken, gaat niemand hier iets aan.

Ik heb gezegd. 


\section{Referenties}

American Psychiatric Association (1994). Diagnostic and Statistical Manual of Mental Disorders (fourth edition), Washington DC, American Psychiatric Association.

Bloks, J., van Furth, E. \& Hoek, H. (1999). Behandelingsstrategieen bij anorexia nervosa. Houten/Diegem: Bohn Stafleu van Loghum. Brownell "K.D. \& Fairburn, C.G. (1995). Eating Disorders and Obesity. A comprehensive handbook. Guilford Press, New York.

Carter, J.C., Stewart, A., Dunn, V., \& Fairburn, C.G. (1997). Primary prevention of eating disorders: might it do more harm than good? International Journal of Eating Disorders, 22, 167-172.

De Groot, A.D. (1961). Methodologie. Grondslagen van onderzoek en denken in de gedragswetenschappen. Den Haag: Mouton.

Fairburn \& Walsh, 1995. Atypical eating disorders. In: Brownell, K.D. \& Fairburn, C.G. (eds.), Eating disorders and obesity. A comprehensive textbook, p135-140. The Guilford Press.

Fairburn, C.G. Marcus, M.D. Wilson, G.T.1993 Cognitive-behavioral therapy for binge eating and bulimia nervosa: A comprehensive treatment manual. In: Fairburn, C.G. \& Wilson, G.T. (eds.). Binge eating: Nature, assessment and treatment, p. 361-404. The Guilford Press.

Fairburn, C.G., Norman, P.A., Welch, S.L., O'Connor, M.E., Doll, H.A., Peveler, R.C. (1995). A prospective study of outcome in bulimia 
nervosa and the long term effects of three psycological treatments. Archives of General Psychiatry, 52, 304-312.

Fairburn, C.G., Welch, S.L., Doll, H.A., Davies, B.A., O'Connor, M.E (1997). Risk factors for bulimia nervosa. Archives of General Psychiatry, 54, 509-517.

Fichter, M.M. \& Quadflieg, N. (1999). Six-year course and outcome of anorexia nervosa. International Journal of Eating Disorders, 26, 359-385.

Garfinkel, P.E. \& Garner, D.M. (1982). Anorexila Nervosa. A

Multidimensional Perspective, p.188-213: The Multidetermined

Nature of Anorexia Nervosa. New York: Brunner/Mazel.

Garner, D.M. (1997). Psychoeducational Principles in Treatment. In:

Garner, D.M. \& Garfinkel, P.E. (eds .) Handbook of treatment for eating disorders, p.145-178. The Guilford Press.

Jansen, A. \& Boon, L. (1991). Eetstoornissen en multicausalítteit. De

Psycholoog, 7/8, 325-330.

Mussell, M., Crosby, R., Crow, S., Knopke, A., Peterson, C, Wonderlich, S. \& Mitchell, J. (2000). Utilization of empirically supported psychotherapy treatments for individuals with eating disorders: a survey of psychologists. International Journal of Eating Disorders, $27,230-237$.

Noordenbos, G. (1999). Preventie van eetstoornissen. In: Bloks, J., van Furth, E. \& Hoek, H. (1999). Behandelingsstrategieen bij anorexla nervosa, p. 105-112. Houten/Diegem, Bohn Stafleu van Loghum. 
Persons, J. (1995). Why practicing psychologists are slow to adopt empirically-validated treatments. in: Hayes, S.C., Follette, V.M., Dawes, R.M. \& Grady, K.E. (eds.) Scientific Standards of Psychological Practice: Issues and recommendations, p. 141-158. Reno: Context Press.

Schoemaker, C. (1998). The principles of screening for eating disorders. In Vandereycken, W. \& Noordenbos, G. (eds.) The prevention of eating disorders, p 187-213. Studies in Eating Disorders, An International Series. The Atlene Press, London.

Schoemaker, C., Reas, Williamson \& Zipfel (in press). International Journal of Eating Disorders.

Schulte, D., Kunzel, R., Pepping, G. \& Schulte-Badenberg, T. (1992).

Tailor-made versus standardized therapy of phobic patients.

Advanced Behavior Research and Therapy, 14, 67-92.

Spaans, J. (1998). Slank, slanker, slankst. Over anorexia nervosa en wat je er aan kunt doen. Boom Meppel Amsterdam.

Stice, E., Mazotti, L., Krebs, M. \& Martin, S. (1998). Predictors of

adolescent dieting behaviors: a longitudinal study. Psychology of Addictive Behaviors, 12, 195-205.

Stuurgroep Eetstoornissen Nederland (1998). Eindrapport.

Van Hoeken, D. \& Hoek, H.W. (1999). Epidemiologie. In: Bloks, J., van

Furth, E. \& Hoek, H. (1999). Behandelingsstrategieen bij anorexia nervosa. Houten/Diegem: Bohn Stafleu van Loghum. Vanderlinden, J. (2000). Anorexia Nervosa overwinnen. Tielt: Lannoo. 
Whittal, M.L., Agras, W.S. \& Gould, R.A. (1999). Bulimia Nervosa: a meta-analysis of psychosocial and pharmacological treatments. Behavior Therapy, 30, 117-135.

Wilson, G.T. (1996). Treatment of bulimia nervosa: When CBT fails. Behavior Research and Therapy, 34, 197-212.

Wilson, G.T. (1999). Cognitive behavior therapy for eating disorders: Progress and problems. Behaviour Research and Therapy, 37, S79-S95.

Wilson, G.T., Fairburn, G.C., Agras, W.S. (1997). Cognitive-behavioral therapy for bulimia nervosa. In: Garner, D.M. \& Garfinkel, P.E. (eds.). Handbook of treatment for eating disorders. New York; Guilford Press 